\title{
Designing a Collaborative Arts Program: Implications for Preservice Art Education
}

\author{
Janet S. Fedorenko
}

Almost all teachers at some point during their teaching experiences will be responsible for the education of students with disabilities. Present day classroom student compositions include students with individual needs and learning styles. In the art classroom the process of mainstreaming, that is the placement of students with disabilities into the regular classroom with their peers is not new. Schools continue to battle with theoretical interpretations of federal legislation imposed by Public Law 94-142, The Education for All Handicapped Children Act, passed in 1975. This landmark law established mandatory access to public education for all students regardless of their disabilities. Under this law, schools were required to provide appropriate educational services for all students in order to receive federal funding. The law contains a provision requiring that the student with disabilities "be educated in the least restrictive environment [LRE] that is consistent with his or her educational needs and, insofar as possible, with students without disabilities" (Hallaman \& Kauffman, 1994, p. 32). The diversity of student populations continues to increase as schools attempt to comply with this law. Defining such an environment has been a key issue in the special education debate.

The art classroom is no exception to today's education inclusionary legislation. Art teachers must deal with mainstreamed students. According to Pffeuffer-Guay (1993):

As individuals in special education communities questioned the need for special programs and the validity of continued separation of students, the concept of exceptionality in the classroom gave way to one of diversity. Art teachers were challenged to meet the needs of an extremely diverse population in integrated art classrooms (p. 222).

Art teachers struggle with methods of integrating these students. The teachers faced with the problems of revising their teaching practices and providing effective instruction for all students are, in many cases, unprepared to do so

I first became interested in the possibilities of using art as a teaching method for special education when it became evident to me that the special needs students, whom I was teaching as an art specialist in elementary and secondary school programs, often flourished in my classroom. The potential art might have as a learning tool for special students led me to initiate, develop, and investigate the results of a curriculum that integrated art concepts and production in a learning disabilities classroom (Fedorenko, 1994). My previous site-specific research focused on the study of art as an educational learning tool for students with learning disabilities. It was a collaborative effort between the learning disabilities instructor and myself. We utilized art to facilitate language acquisition through writing and discussion about artworks, enhanced students' self-esteem

Marilyn Zurmuehlen's Working Papers In Art Education 1996-1997 
through art production related to the artworks discussed, and incorporated interdisciplinary team teaching methods by means of collaborative teaching. I determined from this study that there was a need for further investigation of art as an enhancement for students with disabilities and that educational reform in the area of special education should include collaboration between the art specialist and the special education teacher.

\section{Background to the Problem}

Regardless of the type of integration a school has selected, all teachers, whether they are prepared or unprepared, will experience a large student population containing students with a variety of special needs. Hallman and Kauffman (1994) warned, "Because many children with exceptionalities may receive some or most of their instruction in regular classrooms all teachers must be prepared to work with exceptional students" (p. IS-3). Art teachers are no exception. They must be prepared to teach mainstreamed and included students.

As a university supervisor for preservice art education student teachers, I had many opportunities to touch base with practicing art educators in the reality of the teaching world. These art teachers provided me with many insights concerning the integration of students with disabilities who were mainstreamed into their classrooms. During this university assignment in the fall of 1995, I distributed a survey to the practicing art teachers. It asked questions regarding their personal attitudes and beliefs about teaching students with disabilities. Feelings of frustration and insecurity surfaced. One teacher commented,

"I understand they should be included in society and the classroom. I did not choose to teach art to special education students. I chose art education. I did not realize special education would be mainstreamed back when I began this job" (personal communication; 1994).

The majority of the teachers claimed to have little, if any, preparation to teach special needs students. When asked about the sources of their support, most of the teachers responded that they obtained information about specific students or disabilities by seeking assistance from the special education teachers in their buildings.

Their greatest concerns were how to deal with the wide range of disabilities that they encountered and how to provide lessons and projects that were challenging for the able students yet adaptable to the limiting conditions of the students with disabilities. The solutions that they suggested to resolve these problems included better preparation and inservices regarding the special needs, abilities, and limitations of mainstreamed populations.

\section{Teacher Preparation}

Whereas special educators must overcome their inhibitions concerning the use of art in their classrooms, the field of art education needs to address 
problems art educators and preservice art education students experience with regard to their personal conceptions of the limited capabilities of students with disabilities. Blandy (1994) demanded that "we rethink our conceptions of disability and become uncomfortable with the stereotypes that we bring to our encounters with people experiencing disabilities" ( $p$. 179). He maintained that due to art educators' personal biases and misunderstandings concerning the special students, they are ill at ease teaching them. Present art programs for those with disabilities often have been influenced by these misconceptions and are simplistically conceived. They tend to be therapeutic and rehabilitative in nature, constructed around special activities or special art. Providing experiences for art education preservice students to work with students with disabilities may assist in altering their preconceived notions about them. He proposed that future art educators need to be aware of legal aspects of discriminating against students with disabilities, need to become informed about disabilities through literature. and should be involved in fieldwork experiences at sites where persons with disabilities are served.

Williams (1990) conducted a study of preservice education programs which required a course in special education for regular education teachers. Participants were regular classroom teachers who had taken a course as undergraduates and had at least one year of teaching experience. They were surveyed about what improvements in course content they felt were necessary to better their preparation. The teachers found that even a single course had offered some assistance in dealing with mainstreamed or full-inclusion students but advocated for an improvement in the way the material was presented and recommended more field work experience.. When discussing teacher preparation in the area of special needs students, Askamit (1990) stated, "Models for teacher preparation vary considerably. Some programs require a course in special education, some infuse the mainstream into existing undergraduate course(s) while others combine these approaches" (p. 22).

\section{Collaboration}

Collaboration in my previous study was initiated through local university contacts (Fedorenko, 1994). Following that study, I was given the graduate student university teaching assignment as supervisor to art education preservice student teachers. Throughout my assignment I contemplated the role the university might play in strengthening the preparation of preservice art education students for teaching students with disabilities in the art classroom. I believed that the formation of a collaborative learning experience among a university representative, a preservice art education student, and a special education teacher in a local community school would enhance teacher preparation, encourage collaborative learning, and bridge the university and the community school.

The Holmes Group (1990) supported creation of links between community schools and universities. Their collaborative model was designed to improve the teaching profession '[b]y linking experienced teachers' efforts to review their knowledge and advance their status with efforts to improve their 
schools and to prepare new teachers" ( $p . x v$ ). It was the intent of the Holmes Group to enrich teacher education and at the same time to research the needs and effectiveness of teacher development programs. To form a true partnership with the schools, one which is reciprocal, they advised that the Professional Development School (PDS) sites should cultivate collaboration that promotes mutual learning opportunities for all involved: professors, novice teachers, and students.

Inclusion of special needs students in the art classroom is a reality. Educational reform in the special education curriculum is promoting student inclusion in all areas of education, and the art classroom is no exception. I feel that art teacher preparation should be investigated because art teachers continue to face problems related to curriculum delivery for special needs students.

My study, investigation of the development and implementation of an art integration program and special education curriculum, was based on a collaborative curriculum effort of a special education instructor; a preservice art education student; and myself, an art education graduate student. My research was twofold. It focused on the integration of art with a curriculum for students placed in a special education classroom and on the effects of a university/community collaborative teaching process for all those involved.

\section{Purpose of the Study}

The purpose of my study was to initiate and describe the collaboration that took place between the special education teacher, the preservice art education student, and myself in the development of an art integration program in a special education classroom. The effectiveness of the collaboration in curriculum revision and the description of the collaborative efforts and relationships between the community school and the university were explored. It was my objective to answer the following questions:

1. What happens in terms of collaborative development and peer learning when an art education preservice student, a special education teacher, and a university researcher integrate art into a special education program?

2. In what way is community/university collaboration helpful in preparing art education students for teaching special needs students in the mainstreamed or inclusive art classroom?

3. How can a collaborative teaching situation aid a special education teacher, a preservice art education student, and a university graduate student in developing an integrated art program?

\section{Site and Participants}

The site where the research took place was a sixth grade junior high school special education classroom for developmentally handicapped (DH) students located in Columbus, Ohio, in close proximity to The Ohio State 
University. The ages of the students ranged between 11 and 13. Their developmental problems spanned a wide range. These students, the principal, and other staff members were the secondary participants of the study. The primary participants were the special education teacher, Noreen, who had been teaching in the $\mathrm{DH}$ classroom at this school for five years; the preservice art education student, Jancy; and myself, an art education doctoral student and researcher.

\section{Methodology}

The methodology selected for this research project is descriptive case study. An important characteristic that I considered in the design of the study was the subjective nature of the research problem. To insure rich description of the social situation I was studying, I employed the practice commonly termed triangulation. Triangulation, the use of multiple data sources, increases the validity of my findings (Miles and Huberman, 1984). I borrowed techniques from anthropological ethnographic research for data collection; participant observation was documented through the use of field notes, interviews, teacher journals, and document collection in the form of videos and photographs of student work.

Stake(1988) defined an educational case study as one which explores "an educational problem in all its personal and social complexity" (p. 254). Stake further described a case study in this way: "The case study focuses on a bounded system.... What is being studied is the case. The case is something deemed worthy of close watch. It has character, it has a totality, it has boundaries" (p. 256).

\section{Data Analysis}

Spradiey (1979) observed that analyzing the data collected in a participant observation study requires a search for patterns that emerge throughout the data collection. During this study I used the data analysis method described by Glesne and Peshkin (1992), that includes writing memos within the field log collections, developing analytical files, applying rudimentary coding systems, and sorting and recoding through data display.

The written account of the data analysis is a descriptive case study of the collaboration of the teachers. Taking the suggestion of Glesne and Peshkin (1992), my story was constructed "like that of a painter whose vision emerges over time from intuition, sense, and feeling." ( $p$. 151) They continued; "For many, constructing a text is quite possibly some combination of both plan and intuition" (p. 151).

\section{Results and Implications of the Study}

The research findings of the study supported my original convictions; that a collaborative program between an art education preservice student, a special education teacher in a community school, and a university researcher and teacher promotes interdisciplinary curriculum revisions, improves art teacher 
preparation for teaching students with disabilities in the art classroom, and provides an arena for collaborative experiences between universities and community schools. Previous studies (Fedorenko, 1994; Krone, 1978; Ozimo \& Ozimo, 1988) supported an interdisciplinary curriculum that integrated art in a special education curriculum. In each of these studies students with disabilities were provided alternate methods of learning that enhanced their understanding of their traditional curriculum content. My latest research reaffirmed the contention of these previous studies. Results of this present study indicated students improved their verbal language skills when discussing art works, and they developed self confidence through talking about their personal art work. They were proud of their accomplishments. They successfully applied math related concepts to artwork and their confidence when working with monetary figures increased.

The health unit addressed in this special education classroom focused on student self-esteem and encouraged students to develop a sense of personal pride towards their community. This integrative art program often focused on community-based art education and promoted positive attitudes for the students concerning their community. They were excited to learn that art existed in their personal world and they eagerly shared this new found information with their peers.

According to Blandy (1994) and Pffeuffer-Guay (1993, 1994), art teacher preparation programs have not adequately prepared teachers to teach students with disabilities who are mainstreamed or included in the art classroom. My study provided a preservice art education teacher fieldwork experience in teaching students with disabilities. Results indicated that because of the fieldwork experience, the preservice student increased her confidence when teaching students with disabilities, became less frustrated and biased concerning the abilities of these students, and was introduced collaborative interdisciplinary planning and teaching methodology.

Barry (1994) and CEC (1994) did studies that both support collaborative teaching as a way to deal with the inclusion of students with disabilities. Both studies found that the development of partnerships between teachers encourages teachers to integrate curriculum methods that address the needs of students with disabilities. It was suggested that by providing teachers with experiences in collaborative programs, they may develop confidence and be willing to undertake such an endeavor again. In my study, all of the primary participants were introduced to collaborative teaching. Results indicated that at the onset of the program the teachers involved in this study often experienced problems related to unfamiliarity with collaboration, territorial domain issues, and the flexibility necessary in exchanging teachers' roles and responsibilities. As the program progressed, the teachers became more willing to share responsibilities, to cross previous territorial boundaries, and to participate as eam teachers. Through this collaborative experience teachers developed flexibility and were more comfortable in collaborating together. 


\section{Suggestions for Further Research}

This study examined art teacher preparation with regard to teaching students with disabilities and supports previous studies that suggest preservice programs should provide students with fieldwork experiences in teaching special populations. (Blandy, 1993; 1994; Pffueffer-Guay, 1993) This study supports the belief that universities need examine their present regular education and art education programs and should investigate program models that promote teacher preparation in the area of special education.

My study relied on the collaboration of a special education teacher, an art education preservice student, and myself, an art educator and university researcher. It contended that the effectiveness of collaborations may be reliant on several key issues; mutual initiation of the program, a sharing of leadership, and a strong commitment to the endeavor. Further studies that promote opportunities for collaboration between teachers might assist in developing teacher flexibility and confidence in such endeavors and encourage them to support future collaborative teaching methods.

This study also advocated that teachers, preservice students, and educational researchers can benefit from collaboration between community schools and local universities. It illustrated that university personnel can and should conduct research that promotes a sharing of knowledge with public school teachers. Additional studies may included the investigation of collaborative endeavors between university researchers and community schools. Future studies might investigate the possibilities of incorporating art in a curriculum for students with disabilities through collaboration.

Although not a initial aspect of the research, much of the interdisciplinary program we introduced focused on art within the local community. This community based art education component of the curriculum encouraged students to become active members of the physical community in which they lived. This evolutionary emergence illustrated the positive effects of community based curriculum. Future curriculum studies might include investigation of community art resources and their inclusion in interdisciplinary programs for students.

In my collaborative study, I, as a university researcher, supervised a program that linked the university with community schools. I was able to observe educational theories that support collaboration being applied to teaching practices. My study afforded the special education teacher in a community school an opportunity to learn art methods applicable to interdisciplinary teaching through curriculum planning with the preservice art education student and myself. In turn, the special education teacher became an invaluable resource for the preservice student by providing insight as to the abilities of the special needs students. This study suggests many avenues for further research in the areas of teacher preparation, collaboration, and curriculum revision. 


\section{References}

Aksamit, D. L. (1990). Practicing teachers' perceptions of their preservice preparation for mainstreaming. Teacher Education and Special Education, 13(1), 21-29.

Blandy, D. (1994). Assuming responsibility: Disability rights and the preparation of art educators. Studies in Art Education, 35(3), 179-187.

Blandy, D., \& Hoffman, E. (1993). Toward an art education of place. Studies in Art Education, 35(1), 22-33.

Council for Exceptional Children. (1994). Creating schools for all our students: What 12 schools have to say. Reston, VA: Council for Exceptional Children.

Fedorenko, J. (1994). Art in special education: A study in collaboration. Unpublished master's thesis, The Ohio State University, Columbus, $\mathrm{OH}$.

Glesne, C. \& Peshkin, A. (1992). Becoming qualitative researchers. White Plains, New York: Longman Publishing Group.

Goebel, A., \& Gowland, D. (1982). One approach to art in special education. Education Canada, 22(1), 20-24.

Hallman, D. P. \& Kauffman, J. M. (1994). Exceptional children: Introduction to special education, (6th ed.). Needham Heights, MA: Allyn and Bacon.

Holmes Group. (1990) Tomorrow's Schools: Principles for the design of the professional development schools. East Lansing. Ml: The Holmes Group.

Krone, A. (1978). Art instruction for handicapped children. Denver, CO: Love Publishing Co.

Miles, M. B. \& Huberman, A. M. (1984). Qualitative data analysis: A sourcebook of new methods. Newbury Park, CA: Sage Publications, Inc

Omizo, M. M., \& Omiz, S. A. (1988). Intervention through art. Academic Therapy, 24(1), 103-106.

Pfeuffer-Guay, D. M. (1994). Cross-site analysis of teaching practices: Visual art education with students experiencing disabilities. Studies in Art Education, 34(4), 222-232.

Pfeuffer Guay, D. M. (1993). Normalization in art with extra challenged students: A problem solving framework. Art Education, 46(1), 58-63. 
Silver, R. A. (1978). Developing cognitive and creative skills through art. Baltimore, MD. University Park Press.

Spradley, J.P. (1979). The ethnographic interview. Orlando, FLA: Holt, Rinehart, and Winston, Inc.

Stake, R. E. (1988). Case study methods in educational research: Seeking sweet water. In Jaeger, R. M. (Ed.), Complimentary methods for research in education (pp. 254-265). Washington, D. C: Educational Research Association.

Williams, D. (1990). Listening to today's teachers: They can tell us what tomorrow's teachers should know. Teacher Education and Special Education, 13(3-4), 149-153. 